\title{
Chemical Constituents from the Barks of Swietenia macrophylla
}

\author{
Liwen Tian, ${ }^{a}$ Xifeng Teng, ${ }^{b}$ Cheng Zhong, ${ }^{a}$ and Yang Xie ${ }^{*, a}$ \\ ${ }^{a}$ School of Pharmceutical Sciences, Southern Medical University, Guangzhou, Guangdong 510515, China \\ ${ }^{b}$ School of Traditional Chinese Materia, Guangdong Pharmceutical University, Guangzhou, \\ Guangdong 510006, China
}

\begin{abstract}
A new tirucallane-type triterpenoid, swietentol (1), was isolated from the barks of Swietenia macrophylla, together with four known triterpenoids (2-5), five known limonoids $(\mathbf{6}-\mathbf{1 0})$, and other six compounds (11-16). The structure of swietentol (1) was elucidated by extenstive 2D NMR and MS analysis.
\end{abstract}

Keywords Swietenia macrophylla, Melicaeae, tirucallane-type triterpenoids, limonoids

\section{Introduction}

Swietenia macrophylla King (Melicaeae), a big-leaf mahogany tree, is an endangered and medicinally important plant indigenous to tropical and subtropical regions in the world, such as India, Indonesia, Malaysia, Philippines, and Fiji. ${ }^{[1]}$ Its seeds have been used as a folk medicine for treatment of diabetes, hypertension, and malaria in Malaysia. ${ }^{[2]}$ Previous chemical investigation of Swietenia macrophylla led to the isolation of a number of limonoids, ${ }^{[3,4]}$ steroids $^{[5]}$ and polyphenols, ${ }^{[6]}$ which showed a wide spectrum of biological effects, such as anti-viral, anti-inflammatory, anti-infective, anti-mutagenic, and anti-diabetic activities. ${ }^{[2]}$ In this paper, a new tirucallane-type triterpenoid, swietentol (1), was isolated from the barks of $S$. macrophylla, along with four known triterpenoids (2-5), five known limonoids $(\mathbf{6}-\mathbf{1 0})$, and other six compounds $(\mathbf{1 1}-\mathbf{1 6})$. Their structures are shown in Figure 1

\section{Experimental}

\section{General procedures}

Optical rotations were measured with a Perkin Elmer 341 polarimeter, and NMR spectra were recorded at $30{ }^{\circ} \mathrm{C}$ on a Varian $400 \mathrm{MHz}$ unity spectrometer. The ${ }^{1} \mathrm{H}$ NMR and ${ }^{13} \mathrm{C}$ NMR chemical shifts were referenced to the solvent peak for DMSO- $d_{6}$ or $\mathrm{CDCl}_{3}$, HRESI-MS spectra were recorded on a Waters ZQ mass spectrometers. Column chromatography was performed on MCI gel CHP 20P (75-150 $\mu \mathrm{m}$, Mitsubishi Chemical Co.), Sephadex LH-20 (25-100 $\mu \mathrm{m}$, Pharmcia Fine Chemical Co.), and ODS (150-200 mesh, Merck). Precoated
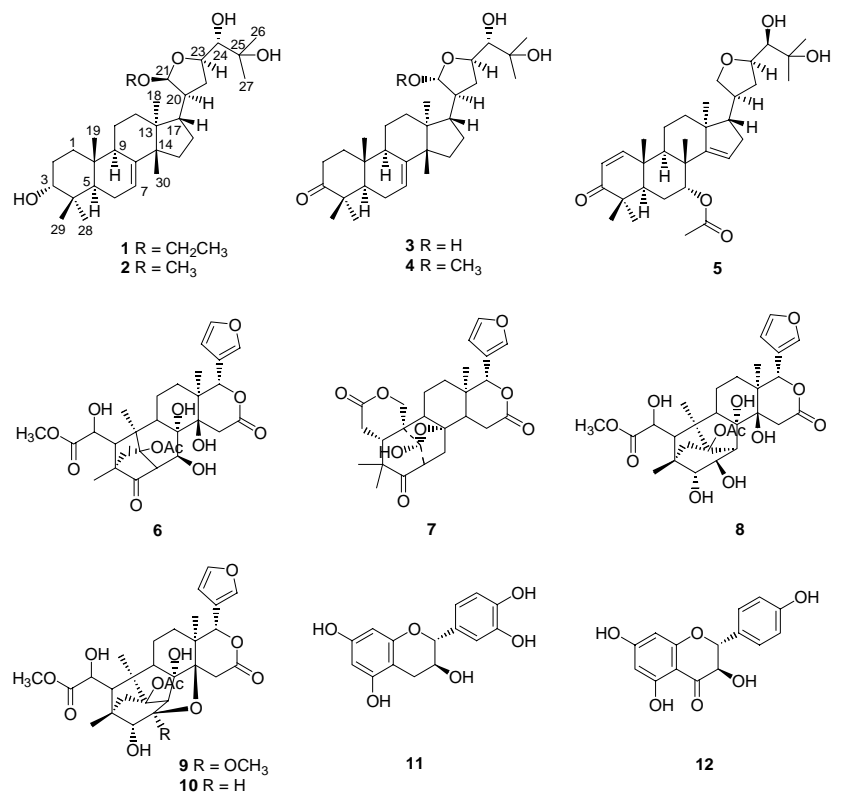

11

12

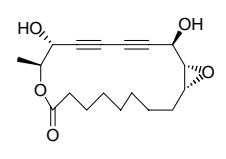

13

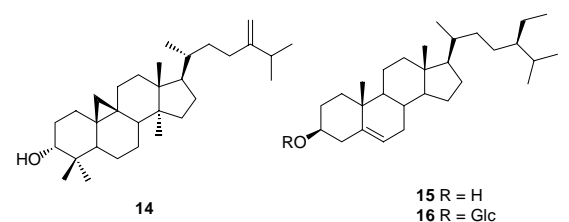

Figure 1 The structures of compounds $\mathbf{1}-\mathbf{1 6}$.

silica gel plate (Qingdao Hailang Chemical Co.) was used for TLC. A waters 600 pump equipped with a Waters 2487 detector was used for HPLC. A thermo Scientific C18 Hypersil $5 \mu \mathrm{m}$ column was used for semi-preparative HPLC seperation.

\footnotetext{
* E-mail: yxie201203@126.com; Tel.: 0086-020-61648593; Fax: 0086-020-61648533

Received June 29, 2015; accepted July 13, 2015; published online July 27, 2015.

Supporting information for this article is available on the WWW under http://www.genchemistry.org.
} 


\section{Plant materials}

The plant $S$. macrophylla was collected from the campus of Guangdong Pharmceutical University in Guangzhou, China. It was air-dired prior to extraction. A voucher sample (NPC-201301) has been lodeged at the Natural Product Chemistry Lab in School of Pharmceutical Sciences, Southern Medical University, Guangzhou, China.

\section{Extraction and isolation}

The grounded barks of $S$. macrophylla (14.0 kg) were refluxed with $\mathrm{MeOH}$ at $80{ }^{\circ} \mathrm{C}(3 \times 10 \mathrm{~L}, 4 \mathrm{~h}$ per time). The extracts were concentrated under reduced pressure and then suspended in water, which was further partitioned with EtOAc $(5 \times 3 \mathrm{~L})$. The EtOAc soluable fraction (204.6 g) was subjected to silica gel column chromatography $(\mathrm{CC})$, eluting with $\mathrm{CHCl}_{3} / \mathrm{MeOH}$ $(0 / 1-1 / 1)$ to afford seven fractions. Fr. 2 (25.6 g) was chromatographed over silica gel (PE/EtOAc, 9/1$1 / 1)$ and $\mathrm{ODS}\left(\mathrm{MeOH} / \mathrm{H}_{2} \mathrm{O}, 60 \%-100 \%\right)$ to yield 4 (18 $\mathrm{mg}), 14$ (20 mg), and 15 (0.5 g). Fr. 3 (19.6 g) was subjected to CC over MCI CHP 20P to yield 11 (2.4 g). Fr. 4 (6.6 g) was subjected to MCI CHP20P CC to yield four sub-fractions $\mathrm{A}-\mathrm{D}$. Sub-fr. 4B was applied to silica gel $\left(\mathrm{CHCl}_{3} / \mathrm{MeOH}, 40 / 1-10 / 1\right)$, ODS $\left(\mathrm{MeOH} / \mathrm{H}_{2} \mathrm{O}\right.$, $40 \%-80 \%)$, and semi-preparative $\mathrm{HPLC}\left(\mathrm{MeOH} / \mathrm{H}_{2} \mathrm{O}\right.$, $10 \%-100 \%$ within $30 \mathrm{~min})$ to yield $6(10 \mathrm{mg}), 7(35$ $\mathrm{mg}), 8$ (5 mg), 9 (9 mg), and 10 (4 mg). Sub-fr. 4C was subjected to $\mathrm{CC}$ over ODS $\left(\mathrm{MeOH} / \mathrm{H}_{2} \mathrm{O}, 40 \%-80 \%\right)$, and semi-preparative HPLC $\left(\mathrm{MeOH} / \mathrm{H}_{2} \mathrm{O}, 10 \%-100 \%\right.$ within $30 \mathrm{~min})$ to yield $1(6 \mathrm{mg}), 2(14 \mathrm{mg})$, and $13(8$ $\mathrm{mg}$ ). Sub-fr. 4D was chromatographed over silica gel $\left(\mathrm{CHCl}_{3} / \mathrm{MeOH}, 40 / 1-10 / 1\right)$ and $\mathrm{ODS}\left(\mathrm{MeOH} / \mathrm{H}_{2} \mathrm{O}\right.$, $40 \%-80 \%)$ to afford 5 (15 mg). Fr. 6 (14.0 g) was subjected to CC over silica gel (PE/EtOAc, 9/1-1/1) to yield five sub-fractions $\mathrm{A}-\mathrm{E}$. Sub-fr. $6 \mathrm{~A}$ was chromatographed over silica gel $\left(\mathrm{CH}_{2} \mathrm{Cl}_{2} / \mathrm{MeOH}, 100 / 1-10 / 1\right)$ and sephadex LH-20 (100\% MeOH) to yield $15(10 \mathrm{mg})$. Sub-fr. 6B was chromatographed over silica gel $\left(\mathrm{CHCl}_{3} / \mathrm{MeOH}, 40 / 1-10 / 1\right)$ and sephadex LH-20 $(100 \% \mathrm{MeOH})$ to yield 4 (21 mg). Sub-fr. 6C was subjected to $\mathrm{CC}$ over silica gel $\left(\mathrm{CHCl}_{3} / \mathrm{MeOH}, 40 / 1-10 / 1\right)$ and $\mathrm{ODS}\left(\mathrm{MeOH} / \mathrm{H}_{2} \mathrm{O}, 40 \%-100 \% \mathrm{MeOH}\right)$ to yield 12 (24 mg). Sub-fr. 6E was chromatographed over silica gel (PE/EtOAc, 9/1-1/1) and ODS (40\%-100\% $\mathrm{MeOH})$ to yield $3(14 \mathrm{mg})$, and $16(30 \mathrm{mg})$.

Swietenitol (1): amorphous powder; $[\alpha]_{\mathrm{D}}^{28}+25.8(c$ $0.03, \mathrm{MeOH}) ;{ }^{1} \mathrm{H} \mathrm{NMR}\left(\mathrm{CDCl}_{3}, 400 \mathrm{MHz}\right)$ is in Table 1 ; ${ }^{13} \mathrm{C} \mathrm{NMR}\left(\mathrm{CDCl}_{3}, 100 \mathrm{MHz}\right)$ is in Table 1; (+)-HRESIMS: $\mathrm{m} / \mathrm{z} \quad 519.1676 \quad[\mathrm{M}+\mathrm{H}]^{+}$(calcd for $\left.\mathrm{C}_{32} \mathrm{H}_{55} \mathrm{O}_{5}, 519.4049\right)$.

\section{Results and Discussion}

The $\mathrm{MeOH}$ extract of the barks of $S$. macrophylla was suspended in $\mathrm{H}_{2} \mathrm{O}$, and partitioned successively with EtOAc. The EtOAc layer was subjected to vari-
Table $1{ }^{1} \mathrm{H}$ NMR (400 MHz) and ${ }^{13} \mathrm{C}$ NMR (100 MHz) data of compound 1 in $\mathrm{CDCl}_{3}$

\begin{tabular}{|c|c|c|}
\hline Position & $\delta_{\mathrm{H}}$ & $\delta_{\mathrm{C}}$ \\
\hline $1 \alpha$ & $1.47(\mathrm{~m}, 1 \mathrm{H})$ & $31.2\left(\mathrm{CH}_{2}\right)$ \\
\hline $1 \beta$ & $1.33(\mathrm{~m}, 1 \mathrm{H})$ & \\
\hline $2 \alpha$ & $1.63(\mathrm{~m}, 1 \mathrm{H})$ & $25.4\left(\mathrm{CH}_{2}\right)$ \\
\hline $2 \beta$ & $1.93(\mathrm{~m}, 1 \mathrm{H})$ & \\
\hline 3 & 3.48 (br.s, $2 \mathrm{H})$ & $76.2(\mathrm{CH})$ \\
\hline 4 & & $37.4(\mathrm{C})$ \\
\hline 5 & $1.80(\mathrm{dd}, J=5.8,11.9 \mathrm{~Hz}, 1 \mathrm{H})$ & $44.6(\mathrm{CH})$ \\
\hline $6 \alpha$ & $2.00(\mathrm{~m}, 1 \mathrm{H})$ & $23.9\left(\mathrm{CH}_{2}\right)$ \\
\hline $6 \beta$ & $1.93(\mathrm{~m}, 1 \mathrm{H})$ & \\
\hline 7 & $5.28(\mathrm{dd}, J=2.8,6.1 \mathrm{~Hz}, 1 \mathrm{H})$ & $118.2(\mathrm{CH})$ \\
\hline 8 & & $145.8(\mathrm{C})$ \\
\hline 9 & $2.30(\mathrm{~m}, 1 \mathrm{H})$ & $48.4(\mathrm{CH})$ \\
\hline 10 & & $34.8(\mathrm{C})$ \\
\hline $11 \alpha$ & $1.55(\mathrm{~m}, 1 \mathrm{H})$ & $17.4\left(\mathrm{CH}_{2}\right)$ \\
\hline $11 \beta$ & $1.50(\mathrm{~m}, 1 \mathrm{H})$ & \\
\hline $12 \alpha$ & $1.32(\mathrm{~m}, 1 \mathrm{H})$ & $31.2\left(\mathrm{CH}_{2}\right)$ \\
\hline $12 \beta$ & $1.87(\mathrm{~m}, 1 \mathrm{H})$ & \\
\hline 13 & & $43.4(\mathrm{C})$ \\
\hline 14 & & $50.8(\mathrm{C})$ \\
\hline $15 \alpha$ & $1.50(\mathrm{~m}, 1 \mathrm{H})$ & $34.1\left(\mathrm{CH}_{2}\right)$ \\
\hline $15 \beta$ & $1.50(\mathrm{~m}, 1 \mathrm{H})$ & \\
\hline $16 \alpha$ & $1.32(\mathrm{~m}, 1 \mathrm{H})$ & $27.3\left(\mathrm{CH}_{2}\right)$ \\
\hline $16 \beta$ & $1.90(\mathrm{~m}, 1 \mathrm{H})$ & \\
\hline 17 & $2.05(\mathrm{~m}, 1 \mathrm{H})$ & $44.9(\mathrm{CH})$ \\
\hline 18 & $0.87(\mathrm{~s}, 3 \mathrm{H})$ & $23.1\left(\mathrm{CH}_{3}\right)$ \\
\hline 19 & $0.80(\mathrm{~s}, 3 \mathrm{H})$ & $12.9\left(\mathrm{CH}_{3}\right)$ \\
\hline 20 & $1.95(\mathrm{~m}, 1 \mathrm{H})$ & $46.2(\mathrm{CH})$ \\
\hline 21 & $4.83(\mathrm{~d}, J=3.1 \mathrm{~Hz}, 1 \mathrm{H})$ & $103.8(\mathrm{CH})$ \\
\hline $22 \alpha$ & $1.91(\mathrm{~m}, 1 \mathrm{H})$ & $31.7\left(\mathrm{CH}_{2}\right)$ \\
\hline $22 \beta$ & $1.91(\mathrm{~m}, 1 \mathrm{H})$ & \\
\hline 23 & $4.44(\mathrm{~m}, 1 \mathrm{H})$ & $78.6(\mathrm{CH})$ \\
\hline 24 & $3.19(\mathrm{dd}, J=1.9,8.0 \mathrm{~Hz}, 1 \mathrm{H})$ & $76.7(\mathrm{CH})$ \\
\hline 25 & & $73.0(\mathrm{C})$ \\
\hline 26 & $1.28(\mathrm{~s}, 3 \mathrm{H})$ & $26.3\left(\mathrm{CH}_{3}\right)$ \\
\hline 27 & $1.28(\mathrm{~s}, 3 \mathrm{H})$ & $26.2\left(\mathrm{CH}_{3}\right)$ \\
\hline 28 & $0.96(\mathrm{~s}, 3 \mathrm{H})$ & $27.7\left(\mathrm{CH}_{3}\right)$ \\
\hline 29 & $0.94(\mathrm{~s}, 3 \mathrm{H})$ & $21.7\left(\mathrm{CH}_{3}\right)$ \\
\hline 30 & $1.02(\mathrm{~s}, 3 \mathrm{H})$ & $27.2\left(\mathrm{CH}_{3}\right)$ \\
\hline \multirow[t]{2}{*}{$\mathrm{OCH}_{2}$} & $3.77(\mathrm{dq}, J=7.0,14.1 \mathrm{~Hz}, 1 \mathrm{H})$ & $63.7\left(\mathrm{CH}_{2}\right)$ \\
\hline & $3.43(\mathrm{dq}, J=7.0,14.1 \mathrm{~Hz}, 1 \mathrm{H})$ & \\
\hline $\mathrm{CH}_{3}$ & $1.25(\mathrm{t}, J=7.0 \mathrm{~Hz}, 3 \mathrm{H})$ & $15.1\left(\mathrm{CH}_{3}\right)$ \\
\hline
\end{tabular}

ous column chromatographies to yield a new tirucallane-type triterpenoid, sweitenitol (1). In addition, 15 known compounds were identified to be agladupol D (2), ${ }^{[7]} 21 \alpha$-meliandiol (3), $21 \alpha$-methylmeliandiol (4), ${ }^{[8]}$ 
protoxylocarpins $\mathrm{F}(5),{ }^{[9]}$ methyl $1 \alpha$-acetoxy$6,8 \alpha, 14 \beta, 30 \beta$-tetrahydroxy-3-oxo-[3.3.1 $\left.1^{10,2} \cdot 1^{1,4}\right]$-tricyclomeliac-7-oate $(6),{ }^{[10]}$ seneganolide $(7),{ }^{[11]}$ methyl $1 \alpha$-acetoxy- $2 \beta, 3 \alpha, 6,8 \alpha, 14 \beta$-pentahydroxy-[4.2.1 $1^{10,30} .1^{1,4}$ ] -tricyclomeliac-7-oate $(\mathbf{8}),{ }^{[10]}$ methyl $1 \alpha$-acetoxy$3 \beta, 6,8 \alpha$,-trihydroxy- $2 \alpha$-methoxy- $2 \beta, 14 \beta$-epoxy$\left[4.2 .1^{10,30} .1^{1,4}\right]$-tricyclomeliac-7-oate $(\mathbf{9}){ }^{[12]}$ 1-acetylkhayanolide B (10), ${ }^{[13]}(+)$-catechin $(\mathbf{1 1})$, aromadendrin (12), ${ }^{[14]}$ ivorenolide A (13), ${ }^{[15]}$ 24-methylenecycloartanol (14), ${ }^{[16]} \beta$-sitosterol (15), and daucosterol (16) by comparison of their spectroscopic data and physicochemical properties with data reported in the literatures.

Compound 1 was obtained as an amorphous powder. Its HRESI-MS displayed a molecular ion peak at $m / z 519.1676[\mathrm{M}+\mathrm{H}]^{+}$, corresponding to the molecular formula $\mathrm{C}_{32} \mathrm{H}_{55} \mathrm{O}_{5}$ with 6 degrees of unsaturation. The molecular weight of compound $\mathbf{1}$ is 14 mass unit larger than that of compound 2, corresponding a methylene group. The ${ }^{1} \mathrm{H}$ NMR spectrum (Table 1) showed seven tertiary methyl groups $\left(\delta_{\mathrm{H}}: 0.80,0.87,0.94,0.96,1.02\right.$, 1.28 and 1.28), one olefinic proton $\left(\delta_{\mathrm{H}} 5.28\right)$, and six protons bonded to oxygen bearing carbons $\left(\delta_{\mathrm{H}}: 3.19\right.$, $3.48,3.77,3.43,4.83,4.44)$. A total 32 carbons were observed in ${ }^{13} \mathrm{C}$ NMR spectrum, which was furtherly divided by HSQC into a trisubstituted double bond $\left(\delta_{\mathrm{C}}\right.$ : $118.2,145.8$ ), eight methyl, nine $\mathrm{sp}^{3}$ methylene, eight $\mathrm{sp}^{3}$ methine, and five $\mathrm{sp}^{3}$ quaternary carbons. A comparison of the NMR data of compound 1 with those of compound $\mathbf{2}$ indicated that compound $\mathbf{1}$ was an analogue of compound 2, a tirucallane-type triterpenoid. Comparison of the ${ }^{13} \mathrm{C}$ NMR data of compounds $\mathbf{1}$ and $\mathbf{2}$ suggested that two compounds shared the same tetracyclic system, which was confirmed by 2D NMR data. The only difference was the presence of an $O$-ethyl group at C-21 in compound $\mathbf{1}$ instead of the $O$-methyl group in compound 2, which was confirmed by the HMBC correlation from methylene $\left[\delta_{\mathrm{H}} 3.77(\mathrm{dq}, J=7.0\right.$, $14.1 \mathrm{~Hz}, 1 \mathrm{H}), 3.43(\mathrm{dq}, J=7.0,14.1 \mathrm{~Hz}, 1 \mathrm{H})]$ and methyl $\left[\delta_{\mathrm{H}} 1.25(\mathrm{t}, J=7.0 \mathrm{~Hz}, 1 \mathrm{H})\right]$ to $\mathrm{C}-21\left(\delta_{\mathrm{C}} 103.8\right)$. Thus, the planar structure was constructed.

The further analysis of ROESY spectrum showed that the relative configuration of the tetracyclic core and side chain in compound $\mathbf{1}$ was identical to that of compound 2. The ROESY cross-peaks of Me-29/Me-19, $\mathrm{Me}-19 / \mathrm{Me}-30$, and Me-30/H-17 indicated that Me-29, Me-19, Me-30, and H-17 were cofacial and assigned in a $\beta$-orientation. In consequence, the ROESY correlations of Me-28/H-5, H-5/H-9, and H-9/Me-18 suggested that they were $\alpha$-oriented. $\mathrm{H}-3$ was assigned a $\beta$-orientation by ROESY correlation of $\mathrm{H}-3 / \mathrm{Me}-29$. The ROESY correlations of Me-18/H-21, Me-18/H-20, $\mathrm{H}-20 / \mathrm{H} 23$ revealed that $\mathrm{H}-20, \mathrm{H}-21$ and $\mathrm{H}-23$ were $\alpha$-oriented. The chemical shift of C-21 $\left(\delta_{\mathrm{C}} 103.8\right)$ also suggested that $\mathrm{H}-21$ was $\alpha$-oriented. ${ }^{[7]}$ The relative large coupling constant $(J=8.0 \mathrm{~Hz})$ between $\mathrm{OH}$ and $\mathrm{H}-24$, and ROESY correlations of $\mathrm{H}-24 / \mathrm{H}-23$ and $\mathrm{H}-24 / \mathrm{H}-23$, suggested that a inter-molecular hydro- gen bond formed between 24-OH and the oxygen of the furan ring. The small coupling constant $\left(J_{23,24}=1.9 \mathrm{~Hz}\right)$ indicated that they were in a gauche relationship and $\mathrm{H}-24$ was $\beta$-oriented. Thus, the structure of swietenitol (1) was elucidated as showed in Figure 1.

Compound $\mathbf{1}$ is unlikely to be an artifact since ethanol was absent during the process of extraction and isolation. Tirucallane-type triterpenoids $(\mathbf{1}-\mathbf{4})$ and apotirucallane-type triterpenoid (5) were reported from Swietenia macrophylla for the first time. Limonoids (6, 8-10) and ivorenolide A (13) were previously reported from the Khaya species. The re-isolation of these compounds from S. macrophylla indicated the close toxomonical relationship between the genus Khaya and Swietenia.

\section{Conclusions}

Chemical investigation into the barks of S. macrophylla led to the isolation of 16 compounds. Compound 1 is new to the science. It is for the first time to report the triterpenoid isolated from S. macrophylla.

\section{Acknowledgement}

The financial support is from the Southern Medical University Startup Foundation for Young Researcher (Nos. C1031672 and C1031887).

\section{References}

[1] Lemes, M. R.; Gribel, R.; Grattapaglia, D. Mol. Ecol. 2003, 12,2785 .

[2] Moghadamtousi, S. Z.; Goh, B. H.; Chan, C. K.; Shabab, T.; Kadir, H. A. Molecules 2013, 18, 10465.

[3] Lin, B.-D.; Zhang, C.-R.; Yang, S.-P.; Zhang, S.; Wu, Y.; Yue, J.-M. J. Nat. Prod. 2009, 72, 1305.

[4] Lin, B.-D.; Zhang, C.-R.; Yang, S.-P.; Wu, Y.; Yue, J.-M. Chem. Pharm. Bull. 2011, 59, 458.

[5] Chen, J.-J.; Huang, S.-S.; Liao, C.-H.; Wei, D.-C.; Sung, P.-J.; Wang, T.-C.; Cheng, M.-J. Food Chem. 2010, 120, 379.

[6] Wu, S. F.; Lin, C. K.; Chuang, Y. S.; Chang, F. R.; Tseng, C. K.; Wu, Y. C.; Lee, J. C. J. Viral Hepatitis 2012, 19, 364.

[7] Xie, B.-J.; Yang, S.-P.; Chen, H.-D.; Yue, J.-M. J. Nat. Prod. 2007, 70, 1532.

[8] Xu, G. H.; Kim, J. A.; Kim, S. Y.; Ryoo, J. C.; Kim, Y. S.; Jung, S. H.; Kim, M. K.; Lee, S. H. Chem. Pharm. Bull. 2008, 56, 839 .

[9] Pudhom, K.; Sommit, D.; Nuclear, P.; Ngamrojanavanich, N.; Petsom, A. J. Nat. Prod. 2009, 72, 2188.

[10] Olmo, L. R. V.; Silva, M. F. d. G. F. d.; Rodrigues Fo, E.; Vieira, P. C.; Fernandes, J. B.; Marsaioli, A. J.; Pinheiro, A. L.; Vilela, E. F. Phytochemistry 1996, 42, 831.

[11] Nakatani, M.; Abdelgaleil, S. A. M.; Okamura, H.; Iwagawa, T.; Doe, M. Chem. Lett. 2000, 29, 876.

[12] Olmo, L. R. V.; da Silva, M. F. d. G. F.; Rodrigues Fo, E.; Vieira, P. C.; Fernandes, J. B.; Pinheiro, A. L.; Vilela, E. F. Phytochemistry 1997, 44, 1157. 
[13] Zhang, H.; Odeku, O. A.; Wang, X.-N.; Yue, J.-M. Phytochemistry 2008, 69, 271.

[14] Takahashi, H.; Kubota, Y.; Iguchi, M.; Fang, L.; Onda, M. Heterocycles 1986, 24, 369.

[15] Zhang, B.; Wang, Y.; Yang, S.-P.; Zhou, Y.; Wu, W.-B.; Tang, W.; Zuo, J.-P.; Li, Y.; Yue, J.-M. J. Am. Chem. Soc. 2012, 134, 20605.

[16] De, P. T.; Urones, J. G.; Marcos, I. S.; Basabe, P.; Cuadrado, M. J. S.; Fernandez Moro, R. Phytochemistry 1987, 26, 1767. 